\title{
SPRAYING TOO EARLY DAMAGES PINE PLANTATIONS
}

\author{
BY N. R. WALKER ${ }^{1}$
}

Oxf. $414.22: 174.7$

In 1965 aerial spraying with herbicides was carried out in the Interlake area of Manitoba on three- to six-year-old plantations of white spruce (Picea glauca (Moench) Voss), black spruce (Picea mariana (Mill.) B.S.P.), jack pine (Pinus banksiana Lamb.), and red pine (Pinus resinosa Ait.). The treatment was intended to kill the overtopping young trembling aspen trees and suckers (Populus tremuloides Michx.), hazel (Corylus cornuta Marsh.), willows (Salix spp.) and lesser vegetation.

Spraying was carried out between 7 a.m. and 8 a.m. on August 5, a day that was calm and clear. A Super Piper Cub with a spray-carrying capacity of 80 gallons was used. Four gallons of aqueous solution containing 15 ounces acid equivalent of 2,4-D and 15 ounces acid equivalent of 2,4,5-T were applied per acre. In addition 1 ounce of plyac detergent was added to each 30 gallons of mixture. Good coverage was obtained.

On October 18, 1965 the sprayed area was inspected; observations of arrested abscission indicated a good leaf kill on young aspen trees and suckers and an excellent leaf kill on hazel, willow and lesser vegetation. White spruce and black spruce were not visibly affected by the spray, but damage to red pine and jack pine was noted.

On June 14-15, 1966 a further assessment of spray damage to the pine plantations was made. Plantations were classified as open (having no overstory protection from applied spray) or protected (overtopped with hazel, willow or aspen). Red and jack pine seedlings within randomly sampled rows were examined. Seedlings were recorded in the following categories: undamaged; reduction in the living crown of 1-25 percent, $26-50$ percent, 51-75 percent and 76-99 percent; and dead.

In open plantations, 26 percent of the jack pine were killed by spray, 51 percent sustained some damage, and only 23 percent remained undamaged. None of the red pine in open plantations were killed, 17 percent were damaged to some extent, and 83 percent were unaffected. Forty-nine percent of the surviving jack pine and 8 percent of the red pine had spray-killed leaders. In the protected plantations spray damage was considerably reduced for both species (Fig. 1).

Herbicide spraying in early August effectively controlled shrub and herbaceous competition in spruce and pine plantations; however, it caused some damage to red pine and moderate to severe damage to jack pine. Arend (1955), in a report on the tolerance of several conifers in lower Michigan to applications of 2,4-D and 2,4,5-T, found that there was no apparent effect on white spruce after July 15 or on red pine after August 1, but that jack pine sustained some browning of the foliage up to August 15. Results

\footnotetext{
1 Technician (Forest Research), Forestry Branch, Canada Department of Forestry and Rural Development, Manitoba-Saskatchewan Region, Winnipeg, Manitoba.
} 


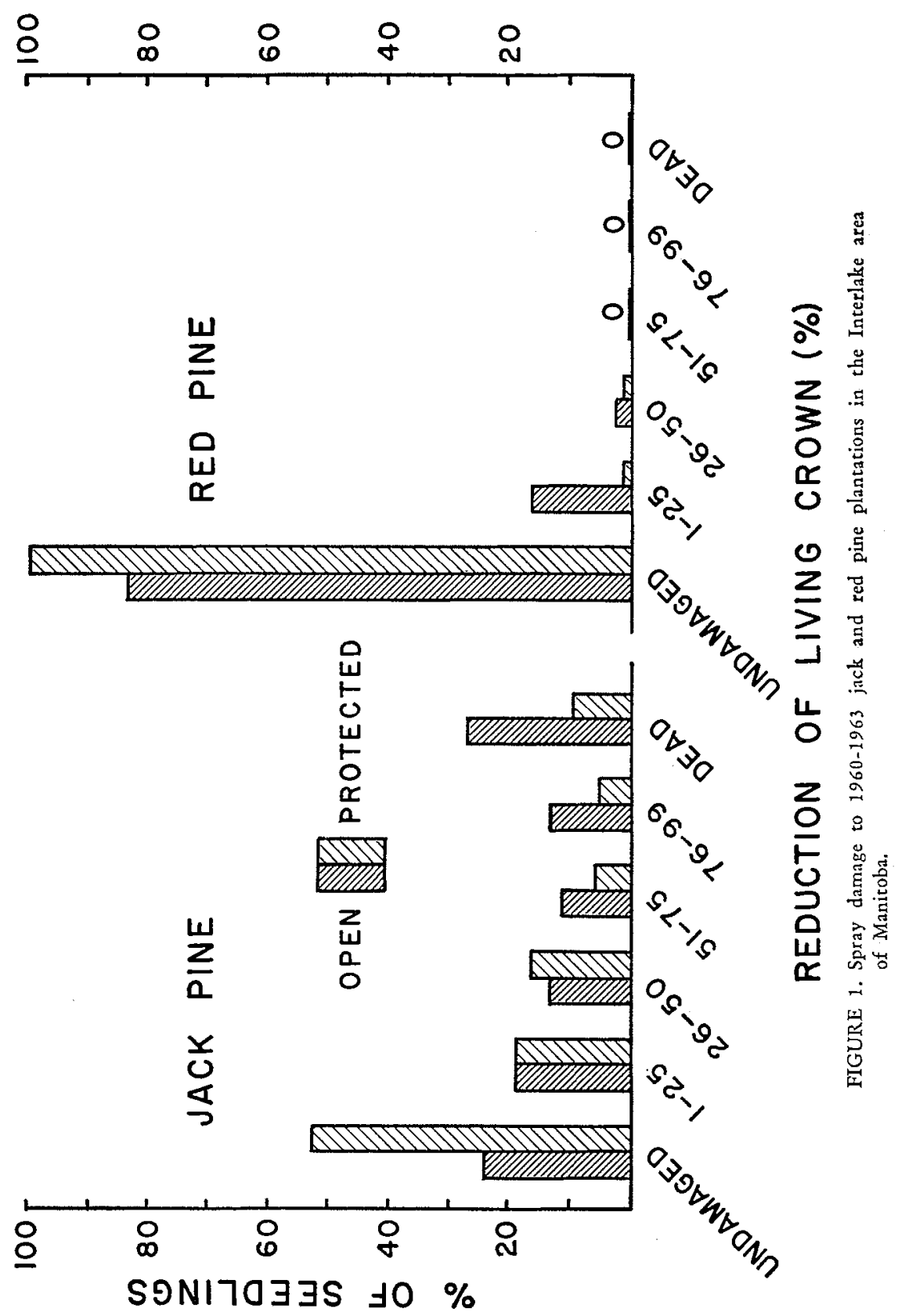


from the present experiment indicate that even though active growth in jack pine seedlings was completed prior to spraying, the physiological changes making them resistant to the herbicide were not yet complete, and that in Manitoba release spraying with 2,4-D and 2,4,5-T should be delayed until well after August 5.

\section{REFERENCE}

AREND, J. L. 1955. Tolerance of conifers to foliage sprays of 2, 4-D and 2,4,5-T in Lower Michigan, U.S.D.A., For. Serv., Lake States For. Expt. Sta.. Tech. Note No. 437,2 pp. 